\title{
STUDI FENOMENOLOGI PERILAKU MAHASISWA PENGGUNA KRS ONLINE
}

\author{
Ria Ayu Purwati \\ Elva Nuraina \\ Elana Era Yusdita* \\ Universitas PGRI Madiun, Jalan Setiabudi 85, Madiun \\ *elaradita@gmail.com
}

\author{
A R T I C L E I N F O \\ Article history: \\ Received August 31, 2020 \\ Revised December 07, 2020 \\ Accepted January 15, 2021
}

\begin{abstract}
Key words:
Perilaku Mahasiswa, KRS Online, Perceived Usefulness, Perceived Ease To Use
\end{abstract}

DOI:

https://doi.org/10.33508/jako.v13i1.2699

\section{PENDAHULUAN}

Majunya teknologi sungguh pesat seiring berkembangnya ilmu pengetahuan, inovasi selalu tercipta untuk memberikan manfaat bagi kehidupan manusia yang saat ini sedang ada di era revolusi 4.0 dengan teknologi yang semakin canggih. Sebagai mahasiswa harus memprogram mata kuliah yang akan diambil dalam setiap semester yang sering disebut sebagai KRS-an yang dimana input data mata kuliah pada Kartu Rencana Studi (KRS) tersebut dilakukan oleh masing-masing individu. Pemrograman KRS oleh mahasiswa penting karena untuk menentukan mata kuliah, jadwal dan kelas

\begin{abstract}
A B S T R A C T
Based on the phenomenon of lack of confidence when programming KRS online, the research was conducted to describe the perceptions of students of class 2016 using related to payment bill information and to show how confident they are to use so that it affects their behavior. The study was conducted on students from 2016 with 7 qualitative with a phenomenological approach and data collection by means of interviews and participant observation. The results show that student behavior as responsive and fast, willing to use it alone without having to be represented shows that students feel comfortable. Behavior that can be seen from the perception of ease perceived convenience and usefulness could be factors that affect the smoothness of
\end{abstract} A B S T R A K

Berdasarkan fenomena kurang percaya diri ketika memprogram KRS secara daring, maka penelitian dilakukan untuk mendeskripsikan persepsi mahasiswa angkatan 2016 pengguna KRS online pada Sistem Informasi Manajemen Universitas PGRI Madiun yang berkaitan dengan informasi tagihan pembayaran dan menunjukan erapa yakin menggunakan sehingga mempengaruhi perilakunya. Penelitian dilakukan pada mahasiswa angkatan 2016 dengan jumlah informan 7 orang dari 3 fakultas yaitu FKIP, FEB dan FT. Metode yang digunakan kualitatif dengan observasi partisipan. Hasil menunjukkan perilaku mahasiswa yang terlihat dari persepsi kebermanfaatan memiliki sikap santai dan tidak ribet, sikap tanggap dan mahasiswa merasa nyaman. Perilaku yang terlihat dari persepsi kemudahan adanya sikap percaya diri, lebih santai, sikap berhati-hati, tidak bingung karena langkah jelas. Kemudahan dan kebermanfaatan yang dirasakan bisa menjadi faktor yang mempengaruhi lancarnya pendapatan UNIPMA. pada semester yang akan dijalankan dengan mengikuti seluruh rangkaian alur dalam sistem informasi akademik, yang kemudian akan muncul rincian tagihan pembayaran yang harus dilunasi oleh mahasiswa. KRS telah mengalami perubahan yang awalnya dilakukan secara manual menggunakan kertas Kartu Rencana Studi hingga akhirnya berganti secara daring atau terkomputerisasi. Mahasiswa IKIP PGRI MADIUN, STT Dharma Iswara, STIE Dharma Iswara angkatan 2016 masih merasakan sistem KRS secara manual dengan dijadwalkan untuk melakukan KRS berkumpul di dalam kelas bersama dosen PA 
(Penasihat Akademik) kemudian menerima kertas KRS 4 rangkap dengan warna dan fungsi yang berbeda. Sejak 3 Januari 2017, adanya perubahan nama menjadi Universitas PGRI Madiun yang dimana pengembangan akan sistem informasi akademikpun dilakukan melalui website.

Sistem informasi sangat penting guna pengambilan keputusan serta menjalankan kegiatan operasional. Informasi keuangan sangat diperlukan untuk suatu organisasi, karena dari informasi tersebut didapatkan tentang keadaan dan posisi keuangan. Melakukan pemrograman KRS akan berpengaruh terhadap munculnya data informasi terkait tagihan pembayaran yang harus dilunasi oleh mahasiswa sesuai dengan jumlah yang tercantum pada tagihan dan itu menjadi pendapatan tunai bagi pihak Universitas PGRI Madiun.

Ada beberapa peneliti yang meneliti terkait Sistem Informasi Akademik di tempat yang berbeda seperti penelitian yang dilakukan oleh Rakhmadian, Sefaverdiana, dan Rahman (2019) di IKIP Budi Utomo Malang; Riyanto, Soedijono, dan Sunyoto (2018) di Universitas AMIKOM Yogyakarta; Lenawati dan Asnawi (2018) di Universitas PGRI Madiun dari sisi sistem informasi; Handayani dan Sudiana (2015) menggunakan model UTAUT pada STTNAS Yogyakarta; Fatmasari dan Ariandi (2014) di Fakultas Ilmu Komputer Universitas Bina Darma Palembang.

Banyak peneliti terdahulu yang meneliti sistem informasi akademik dan KRS online menggunakan teori Technology Acceptance Model untuk melihat diterima tidaknya sistem tersebut dengan menggunakan dua persepsi yaitu perceived usefulness dan perceived ease to use. Penelitian ini dilakukan di Universitas PGRI Madiun dikarenakan belum ada yang meneliti terkait KRS daring dan informasi tagihan pembayaran mahasiswa yang ada pada riwayat keuangan dalam SIM UNIPMA dan berdasarkan fenomena yang ditemukan peneliti dan dialami, yaitu perilaku mahasiswa yang tidak percaya diri karena takut salah ketika melakukan pemrograman KRS dan belum memanfaatkan informasi tagihan mahasiswa yang ada pada riwayat keuangan. Perbedaan dalam penelitian ini yaitu meneliti sistem informasi khususnya KRS daring menggunakan teori TAM dengan cara wawancara. Peneliti terdahulu melakukan penelitian tersebut menggunakan metode kuantitatif melalui kuesioner untuk mengumpulkan data yang kemudian diolah dan menunjukkan seberapa pengaruhnya. Kesempatan kali ini peneliti melakukan penelitian dengan menggunakan metode kualitatif dengan pendekatan fenomenologi. Wawancara dengan pendekatan fenomenologi akan memberikan informasi secara mendalam dan secara sadar yang diungkapkan oleh informan akan pendapatnya dalam hal manfaat yang dirasakan dan kemudahan yang dirasakan secara detail dan tidak menutup kemungkinan ada saran yang akan diungkapkan.

Tujuan dari penelitian ini untuk mendeskripsikan persepsi mahasiswa angkatan 2016 pengguna KRS online pada Sistem Informasi Manajemen Universitas PGRI Madiun yang berkaitan dengan informasi tagihan pembayaran dan menunjukkan seberapa yakin mahasiswa dalam menggunakan KRS daring, sehingga mempengaruhi perilakunya ketika menggunakan sistem tersebut melalui perceived usefulness dan perceived ease to use. Kontribusi dari penelitian yang dilakukan akan memberikan gambaran akan pengembangan teori sistem informasi akutansi penerimaan kas khususnya pada lembaga pendidikan perguruan tinggi serta memberikan gambaran akan pengembangan terkait dengan akuntansi keperilakuan positif perilaku para pengguna suatu sistem informasi dengan pendekatan fenomenologi. Ada juga kontribusi lain bisa menjadi masukan untuk kenyamanan pengguna serta kepercayaan dalam menggunakan Sistem Informasi Manajemen Universitas PGRI Madiun dan lancarnya siklus pendapatan bagi UNIPMA.

\section{KAJIAN LITERATUR DAN PENGEMBANGAN HIPOTESIS}

Kajian Literatur

Teori Technology Acceptance Model (TAM)

Technology Acceptance Model dalam melakukan tes proses mengambil teknologi informasi digunakan pendekatan teori perilaku dan cara mengetahui diterimanya bagi yang menggunakan akan datangnya teknologi melalui sikap pengguna (Fatmawati, 2015). Banyak penelitian terdahulu yang menyatakan bahwa teori ini berkaitan dengan yang menggunakan mau untuk menerima dan memakai teknologi. Davis (1989) melakukan penelitian terhadap TAM yang menyatakan bahwa yang menjadi dasar penentu pengguna menggunakan dua pendapat yaitu, pendapat tentang manfaat yang dirasakan dan pendapat merasa mudah dalam menggunakan, yang dimana manfaat yang dirasakan berkorelasi kuat dengan penerimaan pengguna dan tidak diperbolehkan diabaikan oleh mereka yang berusaha merancang atau mengimplementasikan kesuksesan sistem. 
TAM popular di penelitian keperilakuan dan dapat diaplikasikan ke berbagai tema penelitian. Berikut ini model TAM (Davis, Bagozzi dan Warshaw, 1989):

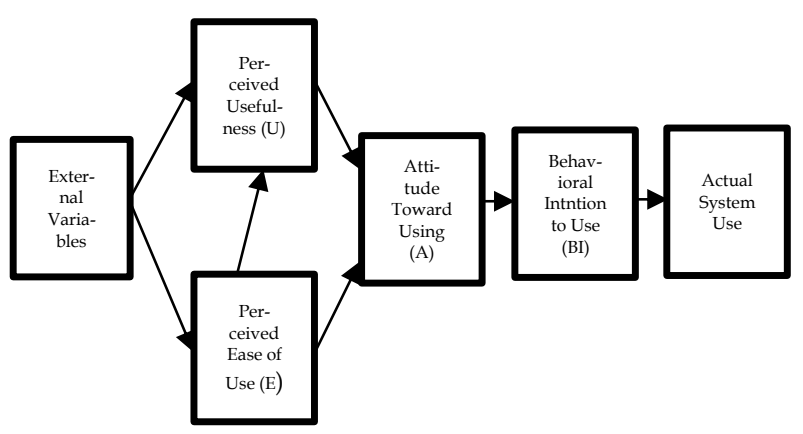

Gambar 1. Technology Acceptance Model

\section{Perceived Ease to Use}

Seberapa orang yakin kalau komputer mudah dipahami dan dioperasikan merupakan definisi dari persepsi tentang kemudahan pengguna teknologi (Saputra dan Misfariyan, 2013). Dikatakan hal serupa oleh Davis (1989) semakin mudah untuk berinteraksi semakin sedikit upaya yang diperlukan untuk mengoperasikan dan semakin upaya yang dialokasikan serta seberapa jauh seseorang percaya akan bebas dari usaha. Berdasarkan dua pendapat tentang persepsi kemudahan dapat disimpulkan bahwa persepsi akan muncul jika pengguna sistem ataupun teknologi menemukan kemudahan dalam penggunaan, serta mudah dalam memahami penggunaan tersebut. Muncul dari rasa percaya yang tinggi bahwa dengan menggunakan teknologi ataupun sistem akan memberikan kemudahan, hal ini akan membentuk persepsi akan kemudahan menjadi kuat. Riyanto, Soedijono, dan Sunyoto (2018) meneliti unsur kemudahan pada pengguna KRS Universitas AMIKOM Yogyakarta justru menunjukkan bahwa kemudahan tidak mempengaruhi kesuksesan KRS online. Berbeda dengan Budiman (2016) melakukan penelitian di AMIK HASS Bandung tepatnya pada mahasiswa D3 Manajemen Informatika serta Fatmasari dan Ariandi (2014) pada mahasiswa Fakultas Ilmu Komputer Universitas Bina Darma Palembang yang menunjukkan persepsi kemudahan mempengaruhi penggunaan KRS online. Sayangnya, kemudahan yang bagaimana yang mendukung niat bahkan perilaku penggunaan KRS online tidak dapat dijelaskan secara mendalam karena penelitian terdahulu menggunakan kuesioner.

\section{Perceived Usefulness}

Menurut Davis (1989), manfaat yang dirasakan merupakan seberapa jauh seseorang akan yakin bahwasanya menggunakan sistem tertentu akan mempertinggi kinerja pekerjaan. Kepercayaan pengguna sendiri yang akan mempengaruhi persepsi dari kebermanfaatan dari suatu teknologi (Saputra, 2019). Perceived usefulness merupakan suatu persepsi yang muncul ketika pengguna suatu teknologi ataupun sistem informasi yang mendapatkan manfaat atas dasar kepercayaan dari diri sendiri bahwa ini akan memberikan manfaat serta mampu meningkatkan kinerja dalam melakukan suatu pekerjaan. Pengguna jika tidak memiliki keyakinan bahwa teknologi atau sistem informasi yang mereka gunakan tidak akan memberikan manfaat, maka pengguna tersebut tidak akan merasakan manfaat ketika menggunakannya. Fatmasari dan Ariandi (2014) menggunakan variabel persepsian manfaat bagi pengguna KRS online di Fakultas Ilmu Komputer Universitas Bina Darma Palembang dan hasilnya terbukti berpengaruh terhadap penerimaan penggunanya. Namun sekali lagi, karena penelitian terdahulu hanya mewajibkan responden mengisi kuesioner, maka tidak diketahui secara mendalam kebermanfaatan yang bagaimanakah yang dapat mendukung penggunaan KRS online.

\section{Kartu Rencana Studi}

Kartu rencana studi itu sesuatu yang wajib diprogram oleh mahasiswa diawal perkuliahan setiap semesternya, guna menentukan mata kuliah yang akan diambil serta mengetahui informasi kelas dan jadwal. Ada juga informasi terkait identitas dari mahasiswa itu sendiri, nama dosen yang mengampu setiap mata kuliah yang diambil, serta tercantumkan jumlah dari sistem kredit semester yang harus ditempuh oleh seorang mahasiswa.

\section{Sistem Informasi Manajemen}

Sistem informasi manajemen itu segala informasi yang telah terekam dalam suatu jaringan sistem didapatkan dari pengumpulan data-data, diawasi, dan diproses. Melalui proses didapatkan suatu informasi yang akurat yang diperlukan oleh seluruh tingkatan manajemen guna membantu dalam mempertimbangkan untuk memutuskan sesuatu dalam suatu organisasi. Hal tersebut juga berkaitan dengan sistem informasi akuntansi yang merupakan sistem yang dimana melakukan aktivitas pengolahan transaksi operasional yang terjadi untuk nantinya diolah menjadi sebuah informasi yang digunakan untuk mengambil suatu keputusan. 
Sistem Informasi Akuntansi Pendapatan

Menurut Wiguna (2015), siklus pendapatan merupakan peran penting untuk menjamin keberlangsungan hidup perusahaan karena dapat mendatangkan uang atau kas ke perusahaan. Siklus pendapatan terjadi karena adanya kegiatan penjualan yang dimana ada penjualan secara tunai dan secara kredit. Sistem infomasi akuntansi penerimaan kas yang secara langsung berkaitan dengan aktivitas siklus pendapatan. Siklus pendapatan khusus pada lembaga pendidikan menurut Sutinah dan Darmadji (2013) didapat dari penerimaan mahasiswa. Adapun sistem penerimaan kas yang berasal dari pembayaran uang semester mahasiswa memiliki dua fungsi, yaitu: (1) fungsi kas yang dimana pada lembaga pendidikan menerima uang atau kas dari mahasiswa secara online melalui bank yang telah menjalin kerjasama serta fungsi kas selalu memperbarui mahasiswa yang telah melakukan pembayaran uang semester untuk direkap mahasiswa yang belum melunasi pembayaran, (2) fungsi akuntansi pada lembaga pendidikan pencatatan penerimaan kas yang dilakukan berdasarkan transaksi pembayaran uang semester mahasiswa dan dari bantuan pemerintah serta yayasan sesuai dengan jenis perguruan tingginya. Dokumen yang digunakan dalam penerimaan kas secara sah yaitu adanya slip pembayaran uang semester mahasiswa.

\section{Kajian Penelitian yang Relevan}

Ada beberapa peneliti yang meneliti terkait Sistem Informasi Akademik di tempat yang berbeda serta pengguna sistem informasi non akademik, ada peneliti yang meneliti sistem informasi akademik di Universitas PGRI Madiun yang menjelaskan bahwa analisis persentasi variabel tertinggi responden mahasiswa, menu, gambar, pemilihan warna, penggunaan tata bahasa website sistem informasi akademik Universitas PGRI Madiun sangat komunikatif dan mudah diingat. Melalui variabel terkecil pada sistem informasi akademik Universitas PGRI Madiun tidak terdapat menu bantuan saat mengalami kesalahan, belum adanya dokumentasi yang lengkap kegiatan civitas akademika serta menu panduan daring langkah mengakses website khususnya berguna untuk mahasiswa baru (Lenawati dan Asnawi, 2018). Penelitian yang dilakukan oleh Handayani dan Sudiana (2015) tentang penerapan model UTAUT terhadap niat berperilaku yang menggunakan sistem informasi pada sistem informasi akademik STTNAS Yogyakarta dengan memakai variabel ekspektasi kinerja, ekspektasi usaha, faktor sosial, dan kondisi pemfasilitas menunjukkan hasil bahwa variabel ekspektasi usaha memberikan hasil yang tidak signifikan, sedangkan variabel yang lain berpengaruh secara signifikan terhadap niat berperilaku. Penelitian Rakhmadian, Sefaverdiana, dan Rahman (2019) di IKIP Budi Utomo Malang menggunakan metode kuantitatif dengan variabel pendapat tentang manfaat yang dirasakan, pendapat merasakan mudah dalam menggunakan dan niat untuk menggunakan, menunjukkan hasil variabel kemudahan menggunakan tidak berpengaruh siginifikan secara parsial terhadap niat untuk menggunakan, sedangkan variabel pendapat tentang manfaat yang dirasakan berpengaruh signifikan terhadap sikap penggunaan serta memberi pengaruh lebih dominan terhadap niat untuk menggunakan sistem informasi akademik mahasiswa IKIP Budi Utomo Malang. Fatmasari dan Ariandi (2014) melakukan penelitian tentang penerimaan KRS daring mahasiswa Fakultas Ilmu Komputer Universitas Bina Darma Palembang. Peneliti menggunakan kuesioner dalam mengumpulkan data dengan variabel kebermaanfaatan, kemudahan, penerimaan sistem KRS. Menunjukkan hasil kebermanfaatan dan kemudahan berpengaruh terhadap penerimaan penggunanya, semakin tinggi kebermanfaatan KRS online maka menambah penerimaan bagi penggunanya. Riyanto, Soedijono, dan Sunyoto (2018) melakukan penelitian di Universitas AMIKOM Yogyakarta dengan metode kuantitatif pendekatan survei. Peneliti menggunakan variabel terkait kualitas sistem, kualitas dari informasi, merasa mudah, merasa berguna, dan merasa puas yang menunjukan hasil bahwa kualitas sistem tidak berpengaruh terhadap variabel merasa berguna. Hasil selanjutnya menunjukan bahwa kualitas dari informasi dan merasa mudah tidak berpengaruh terhadap variabel merasa puas. 


\section{Kerangka Berpikir}

Adanya perubahan perilaku mahasiswa angkatan 2016 Awal memprogram KRS secara manual pada tahun 2016 Tahun 2017 berganti menjadi KRS online

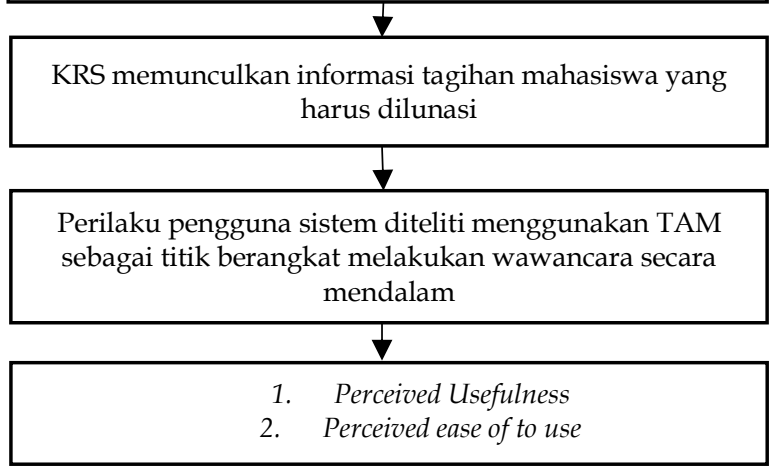

Gambar 2. Kerangka Berfikir Peneliti

\section{METODE PENELITIAN}

Penelitian ini termasuk jenis penelitian kualitatif dengan menggunakan pendekatan studi fenomenologi. Menurut Safitri dan Indriani (2017) fenomenologi adalah ilmu yang tampak pada diri melalui bentuk pengalaman seseorang serta digunakan untuk penjelasan mendalam fenomena berdasarkan pengalaman hidup. Lokasi penelitian dilakukan dimasing-masing informan berada serta lokasi peneliti berada. Adanya perbedaan lokasi antara informan dan peneliti tidak menjadi masalah dikarenakan disesuaikan dengan kondisi saat ini yang mengutamakan Physical Distancing yang mengharuskan melakukan penelitian jarak jauh. Jangka waktu dalaam penelitian ini dimulai bulan Februari hingga Juli 2020.

Peneliti menggunakan sumber data primer dan data sekunder berupa screenshoot dari KRS daring dan informasi tagihan pembayaran. Peneliti menjadikan mahasiswa angkatan 2016 menjadi informan dalam penelitian kali ini dengan jumlah 7 informan dari 3 fakultas. Peneliti mengambil 1 mahasiswa perwakilan dari program studi Akuntansi, 1 mahasiswa perwakilan Manajemen (Fakultas Ekonomi Bisnis), dari Fakultas Teknik diwakili oleh 1 mahasiswa prodi Teknik Informatika. Fakultas Keguruan dan Ilmu Pendidikan diambil 4 informan dari kategori yang berbeda, kategori FPIPS memilih prodi Pendidikan Akuntansi, kategori FIP peneliti memilih prodi Pendidikan Guru Sekolah Dasar, FPBS memilih prodi Pendidikan Bahasa Inggris dan dari kategori FPIPA diwakili oleh prodi Pendidikan Matematika. Peneliti memilih prodi tersebut dikarena memiliki jumlah mahasiswa angkatan 2016 terbanyak di setiap masing-masing kategori. Pedoman wawancara sebagian besar pertanyaan yang diajukan mengacu pada teori Technology Acceptance Model dan disusun sesuai dengan pernyataan yang ada pada angket penelitian yang dilakukan oleh Putra (2019) sebagai berikut:

Tabel 1. Indikator Pertanyaan

\begin{tabular}{|c|l|}
\hline No & \multicolumn{1}{|c|}{ Indikator } \\
\hline \multicolumn{2}{|c|}{ Davis (1989) Persepsi Kemudahan } \\
\hline 1 & Dapat dipelajari secara mandiri \\
\hline 2 & $\begin{array}{l}\text { Memberikan keefektifan untuk mencapai } \\
\text { sesuatu }\end{array}$ \\
\hline 3 & Simbol dan menu tidak ambigu \\
\hline 4 & Mudah dibuka dimana saja \\
\hline 5 & $\begin{array}{l}\text { Tidak memerlukan bimbingan khusus } \\
\text { penggunaan }\end{array}$ \\
\hline 6 & Langkah jelas dan tidak membingungkan \\
\hline Davis (1989) Persepsi Kebermanfaatan \\
\hline 1 & Memberikan efisiensi waktu \\
\hline 2 & Menambah kenyamanan bekerja \\
\hline 3 & Memberikan dampak positif \\
\hline
\end{tabular}

Indikator pertanyaan ini hanya sebagai titik berangkatnya pertanyaan untuk kemudian dikembangkan sesuai jawaban informan karena penelitian ini adalah menggali persepsi pengguna sistem secara mendalam. Cara ini memungkinkan peneliti menangkap hal lain di luar teori TAM dari pernyataan informan, untuk menjawab kekurangan penelitian terdahulu, yaitu aspek persepsi yang bagaimanakah yang dimaksud pengguna sistem. Persepsian kemudahan dan kebermanfaatan juga dapat ditelusuri secara mendalam dengan metode fenomenologi. Peneliti juga tidak bertujuan membuktikan hubungan antarvariabel, tapi menggunakan variabel untuk memancing persepsi pengguna lebih dalam.

Pengumpulan data yang digunakan peneliti melalui observasi partisipan dan wawancara semi terstruktur secara mendalam menggunakan pedoman wawancara yang fleksibel. Pada kali ini peneliti menggunakan triangulasi untuk mengecek kebenaran data ataupun informasi yang didapatkan adapun triangulasi yang digunakan yaitu triangulasi sumber. Proses triangulasi yang akan dilakukan peneliti nantinya membandingkan untuk mencari kesamaan pendapat dari para informan yang telah ditentukan yaitu perwakilan mahasiswa Universitas PGRI Madiun angkatan 2016 dari tiga fakultas berdasarkan indikator yang telah ditentukan. Peneliti memakai teknik analisis data dengan menggunakan 5 kata kunci menurut Kamayanti (2016) ada noema yang dimana peneliti melakukan pemberian tanda kurung pada ungkapan kesadaran yang tampak, noesis mencari 
ungkapan secara sadar akibat pengalaman informan, epoche melakukan pemusatan temuan. intentional analysis menghubungkan noesis membentuk noema melalui aksi atau perilaku yang dialami informan, dan eidetic reduction peneliti mengumpulkan ungkapan hasil sebuah kondensasi dari seluruh pemaknaan yang menjadi kesadaran murni.

\section{HASIL DAN PEMBAHASAN}

\section{Hasil Penelitian}

Berdasarkan hasil penelitian yang dilakukan melalui wawancara peneliti melakukan proses triangulasi untuk mencari kesamaan pendapat, akan tetapi peneliti tidak menunjukkan valid atau tidak valid karena peneliti menggunakan pendekatan fenomenologi yang dimana ungkapan setiap informan berdasarkan yang dialami dan dirasakan. Pembahasan yang dilakukan oleh peneliti dengan mengupas secara mendalam setiap informan pada langkah intentional analysis dan eidetic reduction.

\section{Informan 1}

Informan 1 saat menggunakan SIM UNIPMA memahami sistem informasi manajemen itu sendiri masih belum kontekstual. SIM UNIPMA bagi informan 1 mudah (noema) untuk kampus mengolah data mahasiswa (epoche) dan mudah bagi dirinya sendiri untuk mendapatkan informasi serta menghemat waktu tidak perlu datang ke kampus (epoche) kemungkinan karena jarak rumahnya dengan kampus yang cukup jauh (noesis). Tidak menjadi mudah bagi informan 1 dalam menggunakan SIM UNIPMA bila terjadi loading lama (noema) ketika dibuka bersama (epoche). KRS daring dirasa mudah bagi informan 1 karena informasi yang berkaitan dengan KRS didapatkan melalui handphone pribadinya sehingga tidak perlu datang ke kampus (epoche). Informan 1 juga merasa penting (noema) dengan adanya menu riwayat keuangan yang dapat membantu dirinya untuk mendapatkan informasi jumlah tagihan yang harus dibayarkan (epoche) olehnya sehingga memudahkan dirinya untuk melakukan pelunasan tagihan setiap semesternya. Akan tetapi informan 1 merasa terganggu dengan adanya penerapan waktu 24 jam pada kode virtual account yang ada pada menu riwayat keuangan, mungkin karena informan 1 takut jika tidak sengaja atau teledor mengklik kode tersebut tetapi belum siap untuk melakukan pembayaran tagihan.

"Mungkin untuk hambatan saya rasa hanya ketika itu saja ketika kita klik virtual account jangka waktu kan hanya 1 hari seperti itu"
Hal ini bisa jadi bentuk noesis atau kesadaran terdalam yang secara tidak langsung informan 1 berfikiran bahwa suatu sistem itu harus menyesuaikan kesiapan manusia.

\section{Informan 2}

Bagi informan 2 sistem informasi manajemen itu memberikan data yang cepat dan akurat (epoche) menganggap bahwa ini itu penting. Bagi informan dua dengan adanya menu KRS yang ada pada SIM UNIPMA juga memberikan kemudahan bagi dirinya karena tidak perlu ke kampus untuk ambil kertas KRS seperti yang pernah dialaminya ketika semester awal. Informan 2 merasa bermanfaat menggunakan KRS daring karena menghemat waktunya tinggal pencet-pencet tanpa harus coretcoret di kertas KRS yang jika salah dalam menulis informan 2 harus membeli kertas tersebut dengan harga yang lumayan besar yaitu sepuluh ribu rupiah. Keberadaan informan ketika mengalami susah sinyal maka secara terpaksa harus pergi ke kampus untuk mencari sinyal sekaligus melakukan validasi ke dosen sehingga menjadi tidak mudah bagi informan 2 untuk melakukan KRS daring hal tersebut secara tidak langsung membentuk noesis informan dua menyadari bahwa melakukan pemrograman KRS itu sangat diperlukan sehingga rela datang ke kampus untuk mendapatkan sinyal yang lancar agar bisa melakukan KRS dengan tenang dan lancar. Menu riwayat keuangan bagi informan 2 tidak terlalu penting (noema) dalam hal melihat rincian pembayaran sesuai dengan perkataannya.

"Tidak terlalu penting banget untuk
mengetahui berapa tagihan yang harus kita
bayar untuk setiap semesternya karena kita
sudah dapat informasi dari mulut-kemulut"

Kebiasaan yang terbentuk di kelas informan 2 salah satu temannya sudah melakukan screenshoot rincian pembayaran dan di share ke teman-teman yang lain, sehingga membuat informan dua tidak perlu melihat rincian yang ada di menu riwayat keuangan hanya membutuhkan kode virtual account (epoche) nya saja agar bisa melakukan pembayaran ke bank. Perilaku teman informan 2 mempengaruhi perilaku tidak menggunakan suatu sistem aplikasi secara semestinya. Hal tersebut hampir sama dengan penelitian yang dilakukan oleh Yusdita (2017) yang menyatakan bahwa wajib pajak yang enggan menggunakan e-billing penggunaan aplikasinya dilakukan oleh orang lain yang lebih paham dan mau menggunakan. Informan 2 secara tidak 
langsung mewakilkan kepada temannya untuk menggunakan menu riwayat keuangan dalam hal melihat rician tagihan setiap semesternya.

\section{Informan 3}

Informan 3 memahami suatu sistem informasi manajemen secara kontekstual selaras dengan posisi dirinya sebagai mahasiswa yang membutuhkan data-data yang telah direkap oleh SIM untuk kedepannya. Bagi informan 3 SIM UNIPMA memberikan kemudahan (noema) dalam melakukan kegiatan akademik (epoche) salah satunya pemrograman KRS karena tidak perlu menulis dikertas rangkap 4 seperti pengalamannya dulu ketika semester awal, baginya hal tersebut memberikan manfaat dalam hal efisien tenaga (epoche). Menggunakan SIM UNIPMA informan tiga dengan mudah karena bisa dibuka kapan saja tanpa harus datang ke kampus, akan tetapi menjadi tidak mudah ketika informan 3 mengalami susah sinyal, sama seperti penelitian yang dilakukan oleh Firman, Rahmawati, dan Trijayanto (2017) bahwa pengajuan permohonan izin secara online terpengaruh karena rasa khawatir walau bisa diakses dimana saja akan tetapi tidak dengan jaringan yang tidak bagus, dan juga informan 3 mengalami lemot karena sistemnya penuh. Kurang pahamnya bahasa- bahasa yang ada pada SIM membuat tidak mudah bagi informan tiga misal seperti istilah dashboard yang teringat pada fikiran informan adalah dashboard motor dan mobil yang membuat informan tiga pernah salah klik karena tidak paham akan istilah tersebut sesuai dengan yang dikatakan.

\section{"Nah dashboard itu ada beberapa istilah lain seperti dashboard yang menunya jadwal perkuliahan dan juga ada dashboard lain yaitu contohnya seperti dashboard mobil dan seperti itu.. hahaha"}

Ada juga istilah lain seperti portal dan forum itu kan memiliki makna banyak yang difikirkan oleh informan 3. Rincian yang ada pada menu riwayat keuangan tersebut sebagai bentuk akuntanbilitas kampus dalam hal pembayaran semester mahasiswa. Hal tersebut didukung bahwa akuntabilitas keuangan itu sebagai pengendali keuangan guna meyakinkan memanfaatkan anggaran dana yang diyakini sudah sesuai aturan (Thoyibatun, 2012). Informan 3 juga memanfaatkan rincian tersebut sebagai acuan pembayaran (epoche) selanjutnya karena informan 3 kesadaran terdalamnya mengungkapkan bahwa takut jika telat membayar akan dimarahi oleh orang tuanya (noesis).

\section{Informan 4}

Bagi informan 4 dengan menggunakan SIM UNIPMA tidak perlu ke kampus (epoche) lagi untuk melakukan pemrograman KRS hal tersebut dianggap mudah (noema) baginya karena dulu ketika masih awal-awal pernah mengalami sudah pulang ke Caruban harus kembali lagi ke kampus untuk menyelesaikan KRS pada hari itu juga. Menumenu dan alur yang ada dapat dipahami (noema) secara mandiri oleh informan 4 karena sudah ada petunjuk cara penggunaannya (epoche). Sistem tersebut menjadi tidak mudah ketika informan 4 mengalami server lemot (epoche) yang entah kenapa informan 4 pun juga tidak memahami hanya saja informan 4 berfikir mungkin masuknya bersamaan sehingga menjadi lama. Menjadi tidak mudah bagi informan 4 ketika pemrograman KRS itu untuk mata kuliahnya tidak digolongkan (epoche) masih dijadikan satu seperti itu semua semester dan kelas. KRS secara daring ini bagi informan memberikan manfaat kepada dua belah pihak yaitu kampus yang tidak perlu mengeluarkan budget banyak untuk mencetak kertas KRS dan bagi pihak mahasiswa juga tidak perlu mencetak serta mengedarkan lembar-lembar ke yang bersangkutan. Bagi informan 4, menu riwayat keuangan ini penting (noema) karena ditanyakan oleh orang tua pembayarannya apa saja (epoche), akan tetapi menjadi merasa kurang bermanfaat karena belum terlalu rinci misal seperti rincian pembayaran magang dan KKN masih merasa akuntabilitasnya pihak kampus kepada mahasiswa masih kurang, diungkapkan oleh inforrman 4.

\section{"Nah untuk rincian yang magang itu belum ada jadikan kita mahasiswa itu perlu tahu yang segini itu untuk apa. Ndak magang aja KKN juga hrus diperinci jadi kita tahu bagaimana sih sistem keuangannya rinciannya seperti apa itu kita mahasiswa itu berhak tahu."}

Kode VA sedikit berkurang manfaatnya bagi informan 4 dengan adanya penerapan waktu 24 jam. Peneliti menemukan bracketing saat melakukan analisis yaitu "sia-sia" pada ungkapan informan 4 .

"Jadi ya sia-sia ada waktu 24 jam mungkin itu hanya untuk memberikan peringatan saja pada mahasiswa untuk segera membayar mungkin seperti itu." 
Terkait adanya waktu tersebut karena pernah sudah mengklik kode $V A$ tersebut namun baru membayar sekitar satu minggu setelah itu dan ternyata masih bisa digunakan.

\section{Informan 5}

Bagi informan adanya sistem informasi manajemen itu suatu pengembangan saat ini yang sudah mulai 5.0 (epoche) yang dianggap penting (noema) untuk mengolah data dan mendapatkan informasi aktual yang riil yang dapat diterima oleh mahasiswa (epoche) kembali. Informan 5 merasa mudah (noema) lagi ketika melakukan pemrograman KRS yang tinggal centang-centang (epoche) saja lalu minta validasi ke dosen. Bisa diakses dimana saja yang penting ada jaringan internetnya, membuat informan 5 merasa mudah lagi ketika menggunakan SIM UNIPMA ini. Hal ini sangat berbeda sekali ketika masih KRS manual yang masih harus mengantri dan terkesan grusagrusu dengan adanya secara daring ini informan lima merasa lebih santai (noesis). Sistem tersebut belum adanya pengembangan aplikasi mulai dari awal hingga saaat ini sudah 4 tahun berjalan bagi informan 5, karena informan 5 mengetahui bahwa memang melakukan pengembangan aplikasi itu sulit (noesis) apalagi dengan kapasitas besar. Bagi informan 5 tampilanya flat putih kayak gitu sehingga lama-lama membuat bosan (noesis) diungkapan oleh informan.

"Tapi ya menurut saya ya kayak gitu terlalu flat
ya kayak kita tuh masuk ke apa ya excel kayak
gitu ya"
"Ya mungkin desainnya itu yang membuat kita
itu bosan ya kalau seorang apalagi seorang
desainer teman-temen mahasiswa banyak yang
kreatif itukan melihat SIM itu tiap tahun
modelnya gini-gini aja mungkin ada
pengembangan atau ada tampilannya apa gitu
yang bisa membikin mahasiswa lebih
semangat."

Hal tersebut muncul karena informan 5 pernah melihat tampilan SIM dari universitas lain. User interfacenya yang digunakan pada SIM UNIPMA ini menurut informan 5 masih khusus laptop atau PC belum disesuaikan untuk di handphone. Masih harus menggeser ke kanan ataupun kiri untuk melihat secara keseluruhan menu yang ditampilkan itu membuat menjadi tidak mudah bagi informan 5 . Manfaat lain yang di dapatkan informan 5 ada pada menu riwayat keuangan yang dimana rincian pembayaran menjadi bukti ketika lulus (epoche) nantinya bahwa sudah melunasi semua tagihan selama menempuh pendidikan riwayatnya bisa dilihat di menu tersebut. Walaupun sudah secara otomatis dan terkomputerisasi tapi masih ada proses manual yang terjadi seperti yang pernah dialami oleh informan 5 adanya tagihan yang tidak muncul yang mengantarkan informan 5 akhirnya melapor ke pihak keuangan setelah terproses langsung bisa muncul kembali.

\section{Informan 6}

Informan 6 memahmi sistem informasi manajemen secara kontekstual yang dimana dirasa penting (noema) karena memberikan informasi terkait administrasi kampus dan bimbingan skripsi (epoche) karena informan 6 adalah mahasiswa akhir yang sedang berjuang skripsi. Kemudahan lain yang dirasakan informan 6 ketika melakukan pemrograman KRS secara daring yaitu tinggal mencetang-centang saja tanpa harus ribet menulis dikertas yang sering salah ketika menulis kode mata kuliah dan informan 6 tidak perlu datang ke kampus (epoche) bisa dilakukan di rumah kemudian konfirmasi untuk valiadasi ke dosen. Informan 6 mengungkapkan bahwa

"Saya prodi PBI ada 4 kelas disitu menurut
saya masih kadang membuat bingung juga
apabila semua kelas dan mata kuliahnya
berada dalam satu tabel yang sama sehingga
kita harus memilihnya satu-satu yang cocok
dengan kelas kita dan mata kuliah kita dan
semester kita itupun yang ada 4 kelas saya ya,
belum lagi yang mungkin ada di prodi PGSD
yang banyak kelas mungkin lebih
membingungkan lagi."

Ketidakmudahan yang dirasakan informan 6 pada saat pemrograman KRS yaitu ketika checklist mata kuliah, kelas dan semester yang semua ditampilkan jadi satu sehingga informan 6 harus benar-benar teliti dalam menchecklistnya, hal tersebut dirasa kurang nyaman bagi informan 6 karena bingung kalau dijadikan satu seperti itu. Apa yang dirasakan informan 6 didukung oleh penelitian yang dilakukan oleh Nuryahya, Ichsana, dan Andini (2019) bahwa menu mudah dipahami menjadikan mudah di sistem pencatatan akuntansi keuangan secara teknologi pada E-Commerce ketika digunakan. Pada menu tersebut terincinya riwayat pembayaran mulai awal adanya SIM UNIPMA hingga saat ini semester akhir. Informasi yang ada pada menu tersebut sangat penting (noema) karena 
dibutuhkan oleh orang tua informan 6 (epoche). Informan 6 mengatakan bahwa

"Sehingga kita bisa jelas berapa uang yang harus kita bayar atau dengan kata lain itu transparan gitu lo total pembayaran yang harus kita bayar itu semuanya transparan."

Bagi informan 6 adanya rincian pembayaran tersebut jelas dan transparan (epoche) berapa yang harus dibayarkan serta merasa nyaman karena tidak banyak informasi yang dicantumkan sehingga fokus pada rincian pembayaran. Transparansi keuangan memang sangat penting bagi setiap perguruan tinggi menurut Milad, Wibowo, dan Athoillah (2019) sebagai bentuk peertanggungjawaban dan keputusan terhadap aturan serta ketentuan sebagai peningkatan efektifitas dalam mengawasi terkait pelayanan dan pengembangan serta meningkatkan kepercayaan.

\section{Informan 7}

Semenjak adanya SIM UNIPMA pemrograman KRS dilakukan secara daring oleh informan 7 dengan memanfaatkan menu kartu rencana studi. Kemudahan yang dirasakan informan 7 saat melakukan KRS secara daring sudah tidak melakukan antrian panjang saat seperti KRS manual menggunakan kertas berangkap-rangkap.informan 7 pun merasa mudah (noema) karena tinggal pencet atau klik-klik saja (epoche) tanpa takut salah tulis seperti pengalamannya dulu ketika masih menggunakan kertas dan ketika salah tulis ganti kertas membayar Rp5.000,-. Informan 7 mengungkapkan suatu imajinasi sekaligus harapannya bahwa

\section{"Mungkin bisa andai ada kemudahan lain tu bisa buat transfer tapi juga pake virtual accountnya itu juga bisa gitu kak, tapi sayangnya ya harus masih mengantri ke bank untuk bayar"}

Bagi informan 7 kalau masih ada yang lebih mudah dan praktis lagi tanpa harus mengantri panjang kenapa tidak dibuat seperti itu. Hal tersebut hampir sama dengan penelitian yang dilakukan Yusdita (2017) bahwa keinginan dari wajib pajak yang langsung bayar dan sudah selesai urusannya jika selesai membayar tanpa ada pencatatan, yang menunjukkan bahwa wajib pajak tersebut ingin sistem yang paling sederhana.

\section{Pembahasan}

Menggunakan data yang telah diperoleh peneliti melalui wawancara yang selanjutnya dilakukan analisis data dan dihubungkan dengan teori yang dipakai, sehingga peneliti menganalisis 9 indikator yang mendukung perceived ease to use dan perceived usefullness penggunaan SIM UNIPMA adalah sebagai berikut:

\section{Perceived Ease to Use \\ Dapat Dipelajari secara Mandiri}

Pada indikator dapat dipelajari secara mandiri ini untuk mendukung mengungkapkan persepsi kemudahan yang dirasakan serta perilaku yang nampak dari ketujuh informan. Semua informan secara umum merasa dapat dipelajari secara mandiri mulai dari penggunaan secara keseluruhan SIM UNIPMA, pemrograman KRS secara daringnya saja ataupun menggunakan menu riwayat keuangan. Perilaku dari setiap informan terlihat memiliki versi masing-masing bahwa itu dikatakan "dapat dipelajari secara mandiri" mulai dari informan 1 karena sudah ada sosialisasi untuk langkahnya bagaimana, maka perilaku yang telihat dari menggunakan KRS daring dengan mengingat sendiri apa saja langkah yang sudah dijelaskan ketika sosialisasi serta melakukan hal tersebut secara sendiri hingga akhirnya memiliki perilaku sikap percaya diri ketika melakukan pemrograman KRS secara daring. Perilaku yang tampak pada informan 2 awalnya tidak paham semakin lama paham dengan sendirinya karena sudah melakukan pemrograman KRS daring beberapa kali dan berusaha mencobanya sendiri sehingga informan 2 memiliki perilaku sikap terbiasa hingga akhirnya dapat menerima yang mengarahkan perilaku mau berusaha untuk memahami sendiri agar dapat menggunakan KRS daring secara mandiri. Selanjutnya, perilaku yang terlihat pada informan 3 adanya simbol memiliki nama masing-masing membuatnya mudah untuk memahami secara mandiri sehingga terbentuklah perilaku sikap positif yang dapat melakukan pemrograman KRS daring dengan baik dan secara sendiri. Hal tersebut menunjukkan bahwa perilaku yang berusaha untuk menggunakan handphonenya guna memprogram KRS dianggap mudah karena setiap hari selalu mengoperasikan handphone pribadinya. Informan 5 merasa bahwa menunya tidak ribet yang mempengaruhi sikapnya ketika menggunakan KRS daring terlihat santai dan tidak bingung. Hal tersebut memperlihatkan perilaku bersikap santai dan tenang dan mengikuti seluruh alur dari pemrograman KRS dengan sendirinya. Informan 6 
menunjukan sikap bisa menerima karena menu dan alur mudah dipahami akan tetapi untuk fitur skripsi baginya perlu bimbingan. Hal ini terlihat dari keingintahuannya bagaimana menggunakan fitur tersebut dan karena memang informan 6 benarbenar membutuhkan sehingga perilaku untuk selalu mengikuti arahan dari dosen pembimbing skripsi agar lancar ketika proses penyelesaian skripsi. Informan 7 merasa bahasa sistem tidak berbelit sehingga mempengaruhi perilakunya dalam menggunakan KRS daring semakin mudah dan terhindar dari kesalahan-kesalahan yang mungkin terjadi.

\section{Memberikan Keefektifan untuk Mencapai Sesuatu}

Indikator memberikan keefektifan untuk mencapai sesuatu ini masih mendukung dalam pendapat merasa mudah yang dirasakan informan. Sesuatu yang dimaksudkan disini ada beberapa sesuai dengan yang dialami oleh masing-masing informan. Seperti SIM UNIPMA efektif dan efisien untuk melakukan KRS daring dan menu riwayat keuangan menjadikan mengerti berapa yang harus dilunasi bagi informan 1 sehingga terbentuk perilaku positif untuk tetap menggunakan SIM UNIPMA dengan baik ketika pemrograman KRS daring hingga akhirnya memudahkan mengetahui rincian pembayaran yang harus dilunasi. Selanjutnya untuk informan 2 mencapai sesuatunya berupa nilai transkip yang tersimpan secara online, sehingga saat dibutuhkan saat itu bisa langsung dicetak. Bagi informan 2 perubahan perilaku ketika menggunakan secara online ini lebih simpel dan memiliki sikap perilaku cepat untuk segera memenuhi perintah untuk mengumpulkan transkripnya. Informan 3 mencapai tujuan untuk melihat jadwal, pemrogram KRS, KHS, transkrip, dan saat semester 8 ini untuk mengupload judul skripsi, dari apa yang telah disebutkan menunjukan sikap selalu memanfaatkan fitur yang ada untuk memenuhi kebutuhan informasi dan hak untuk mendapatkan kemudahan selama melakukan proses akademik. Perilaku yang ditunjukan oleh informan 4 mencapai sesuatu dalam hal pembayaran dengan buka $V A$ langsung bilang ke teller bank dan tidak perlu mencatat yang membuat semakin merasa mudah dan tidak terbebani untuk menulis pada slip yang disediakan di bank. untuk informan 5 mencapai sesuatu ketika lulus sebagai bukti rincian pembayaran selama menempuh pendidikan di UNIPMA. Hal tersebut membentuk perilaku merasa aman karena ada bukti yang tersimpan secara online sehingga nantinya jika terjadi suatu miskomunikasi bisa diatasi karena tidak khawatir dengan bukti yang tersimpan secara online. Informan 6 mencapai tujuan untuk semakin mudah melihat riwayat pendidikan dan administrasi kampus yang terlihat dari perilaku positif yang memanfaatkan fitur yang ada khususnya KRS. Perilaku yang terlihat dari informan 7 dalam hal mencapai tujuan untuk mendapatkan informasi tanpa tanya ke pihak kampus langsung buka SIM jam berapapun. Hal tersebut menjadikan informan 7 memliki perilaku yang menganggap mudah untuk mendapatkan atau melihat informasi kapanpun.

\section{Simbol dan Menu Tidak Ambigu}

Indikator simbol dan menu tidak ambigu juga masih mendukung persepsi merasa mudah dalam menggunakan SIM UNIPMA secara keseluruhan. Simbol dan menu yang ada secara umum sudah tidak membingungkan dan mudah dipahami karena menurut informan 1 yang menunjukkan perilaku menganggap mudah dan sikap mau menggunakan KRS daring karena perintahnya jelas. Informan 2 menemukan bahwa sudah lengkap serta jelas bisa dipahami, tata caranya juga mudah dimengerti, menjadikannya untuk bersikap lebih tenang dan percaya karena kemudahan yang didapatkan. Ada beberapa istilah yang masih membingungkan seperti adanya istilah dashboard, portal, dan forum yang dirasakan informan 3 yang menjadikan bersikap lebih hati-hati dan mencari tahu apa yang ada dibalik istilah fitur tersebut sehingga terhindar dari kesalahan dalam menggunakan. Menurut informan 4 untuk mencetak sudah ada simbol print yang membuatnya tidak perlu bingung dan khawatir karena sudah tersedia simbol yang langsung mudah dipahami, informan 5 merasa simbol dan menu dipahami sehingga memunculkan sikap "ya sudah dijalani saja" menggunakan setahun atau dua tahun pasti sudah fasih. Jelas kata-katanya dan tidak terlalu banyak menu yang ada pada menu riwayat keuangan yang ditunjukan dengan perilaku informan 6 yang dengan cepat memahami dan menemukan informasi yang dibutuhkan tanpa harus mengklik menu-menu yang lain. Informan 7 menunjukan perilaku tidak malas menggunakan karena merasa jelas, bahasanya mudah dipahami menunya sudah langsung tidak ada menu di dalam menu seperti itu.

\section{Mudah Dibuka di Mana Saja}

Pada indikator mudah dibuka dimana saja ini mengungkapkan bahwa SIM UNIPMA secara keseluruhan bisa dengan mudah dibuka dimana 
saja. Bisa melakukan KRS di rumah seperti yang dilakukan informan 1, 2, 4, 7. Kemudahan bisa melakukan KRS di rumah membuat informan 1, 2, 4, 7 memiliki perilaku yang santai tidak perlu susahsusah menuju kampus untuk memprogram KRS. Sedangkan perilaku yang ditunjukan informan 3 ketika dipegunungan tidak bisa, menjadikan timbul rasa gelisah karena menjadi tidak mudah lagi dan bagi informan 5 yang penting ada internetnya menjadikan lebih tenang dan aman ketika melakukan pemrograman KRS daring. Perilaku yang ditunjukan informan 6 lebih baik mengalah untuk membukanya pada malam hari karena menganggap bahwa siang hari masih terjadi server penuh.

\section{Tidak Memerlukan Bimbingan Khusus}

Pada poin ini berkaitan dengan indikator pertama dapat dipelajari secara mandiri itu, karena mudah untuk dipelajari sendiri sehingga tidak memerlukan bimbingan dalam menggunakannya. Bagi informan 1, 2, 3, 4, 5 menunjukkan perilaku sikap yang tidak memerlukan bimbingan khusus karena sudah merasakan dan mendapatkan kemudahan dapat dipelajari secara mandiri. Akan tetapi, berbeda dengan perilaku yang ditunjukan oleh informan 6 yang sangat memerlukan bimbingan pada fitur skripsi guna melancarkan proses penyelesaian skripsi yang sedang diperjuangkan dan perilaku yang terlihat dari informan 7 hanya memerlukan bimbingan khusus ketika akan melakukan pemrograman KRS mata kuliah yang mengulang agar tidak terjadi kesalahan.

\section{Langkah Jelas dan Tidak Membingungkan}

Pada indikator ini berhubungan erat dengan dapat dipelajari secara mandiri, simbol, dan menu tidak ambigu, tidak memerlukan bimbingan khusus dalam menggunakan itu mempengaruhi langkah ataupun alurnya. Perilaku yang terlihat dari informan 1, 2, 3, 5, 6, 7 yang merasa jelas dan tidak membingungkan menjadikan mereka memiliki sikap yang tetap mau menggunakan KRS daring karena kemudahan yang dirasakan. Sedangkan informan 4 masih menunjukkan perilaku yang tidak sabaran masih merasa ada yang harus keluar masuk balik lagi tidak langsung ketujuan menjadikannya semakin ribet.

\section{Perceived Usefulness}

\section{Memberikan Efisiensi Waktu}

Indikator ini mendukung mengungkap persespi kebermanfaatan dari penggunaan SIM
UNIPMA. Memberikan efisiensi waktu dirasakan oleh seluruh informan 1, 2, 3, 4, 5, 6, 7 dengan ditunjukkannya perilaku dalam sikap yang tidak menjadi ribet harus bolak balik kampus dan tidak perlu menyibukkan diri untuk jauh-jauh datang ke kampus. Ada perilaku lain yang ditunjukkan oleh informan 3 yaitu yang menjadi senang karena hemat tenaga tidak perlu menulis MK, kode MK serta nama dosen dan informan 5 pun menunjukkan perilaku yang santai, tidak grusa-grusu saat pemrograman KRS serta informan 6 dan informan 7 yang menunjukkan sikap yang cepat dan tanggap dalam hal mendapatkan informasi.

\section{Menambah Kenyamanan Bekerja}

Pada indikator ini mengungkapkan bahwa SIM UNIPMA, KRS daring dan menu riwayat keuangan sudah memberikan kenyamanan dalam melakukan proses akademik selama ini bagi Informan 1, 2, 3, 4, 7. Perilaku yang ditunjukan oleh informan 1, 2, 3, 4, 7 nyaman dalan menggunakan KRS daring karena sangat membantu dalam melakukan proses akademik. Perilaku tersebut nampak dari sikap dari informan yang tetap melakukan pemrograman KRS secara sendiri tanpa diwakilkan oleh orang lain. Terlihat perilaku yang sedikit berbeda yang ditunjukkan oleh informan 5, yaitu perilaku kurang nyaman karena tampilan dari SIM yang flat dan user interface-nya masih belum sesuai jika di HP dan informan 6 menunjukkan sikap bingung dan sedikit malas ketika melakukan checklist MK yang masih jadi satu belum digolongkan.

\section{Memberikan Dampak Positif}

Indikator yang terakhir ini termasuk indikator pendukung dari persepsi kebermanfaatan. Semua memberikan dampak positif yang menunjang proses akademik seperti perilaku yang ditunjukkan oleh informan 1 merasa bahwa dampak positif lebih dirasakan oleh pihak kampus terutama dalam mengolah data. Informan 2, 3, 4, 5, 6, 7 yang menunjukkan perilaku yang mendapatkan dampak postif bagi dirinya sendiri sehingga tetap bertahan menggunakan SIM UNIPMA untuk memprogram KRS, karena itu merupakan suatu kewajiban. Perilaku yang tercermin dari mahasiswa pengguna KRS daring ini menunjukkan sikap yang berbedabeda yang dimana sikap tersebut mengungkap seberapa mudah dan bermanfaatnya sistem itu. Perilaku yang tercermin itu dapat mempengaruhi kecepatan dan ketepatan dari penggunaan suatu sistem. Hal tersebut berkaitan dengan respon yang yang dimunculkan dari suatu sistem yang dimana 
semakin yakin pengguna sistem akan mudahnya dan memberikan manfaat baginya maka suatu sistempun akan berproses dengan baik dan tidak sia-sia. Perilaku mahasiswa yang merasa lebih santai dan tidak merasa ribet harus bolak-balik tersebut akan mengurangi beban dari mahasiswa berupa biaya transportasi. Adanya sistem ini membantu mahasiswa untuk lebih hemat karena biaya yang harus dikelurkan sedikit terminimalisir dan nantinya bisa disisihkan untuk memenuhi tanggungjawab sebagai mahasiswa setelah melakukan pemrograman KRS yaitu pelunasan tagihan yang muncul pada riwayat keuangan. Adapula perilaku mahasiswa yang tanggap dan cepat dalam mendapatkan informasi itupun juga mempengaruhi lancarnya siklus pendapatan kampus. Seperti halnya setelah melakukan pemrograman KRS muncullah tagihan yang dapat dibayarkan oleh mahasiswa tersebut, maka mahasiswa bisa langsung segera menindaklanjuti untuk mempersiapkan dana lebih cepat dan bisa memperkirakan kapan harus membayar dan semisal akan melakukan angsuran harus memperhitungkannya dengan acuan informasi tagihan tersebut. Informasi tagihan pembayaran tersebut sangat diperlukan untuk mempertimbangkan dalam hal mempersiapkan dana agar nantinya dapat membayar dengan tepat waktu dan tindakan tersebut pastinya akan berdampak positif bagi kampus karena pendapatan yang diterima kampus lebih cepat dan terproses dengan baik. Sebagai mahasiswa pastilah harus pandai mengatur keuangan dengan mempertimbangkan pengeluaran yang diperlukan untuk memenuhi segala kewajibannya sebagai mahasiswa selama menempuh pendidikan. Dari sistem ini khususnya pada menu riwayat keuangan itu mahasiswa bisa menggunakan rincian informasi pembayaran tersebut untuk mempersiapkan pembayaran di semester berikutnya bagaimana jika menambah SKS dan bagaimana jika mengurangi SKS. Hal tersebut dapat dilakukan oleh mahasiswa secara mandiri dapat bertanggungjawab terhadap pengelolaan keuangan pribadinya.

Sistem dapat mempengaruhi perilaku pengguna sistem. Hal inilah yang dimanfaatkan oleh lembaga pendidikan untuk menyajikan tagihan keuangan kepada mahasiswa sejelas mungkin dengan harapan mencapai tingkat ketepatan waktu pembayaran yang tinggi dan bahkan menghindari SPP tak tertagih. Kemudahan penggunaan sistem terbukti mendukung keteraksesan tagihan. Selain itu, detail pembayaran nyatanya tak hanya mempengaruhi pengguna sistem langsung, yaitu mahasiswa, tapi juga orang tua sebagai sumber pendanaan pendidikan anak. Orang tua juga butuh informasi yang dapat dipercaya dan rincian tagihan keuangan detail. Informasi ini, secara lebih jauh, dapat menghindari penyelewengan uang SPP oleh mahasiswa. Pembayaran SPP adalah hal krusial bagi lembaga pendidikan karena sebagian besar kegiatan operasionalnya dibiayai dari SPP mahasiswa. Selain itu, pihak pengembang dapat menggunakan hasil penelitian ini untuk mempermudah akses dan jika dimungkinkan menambah rincian, tanggal jatuh tempo serta informasi tagihan semester lalu tampil dalam satu laman/tampilan sebagai pengingat dan informasi terhadap orang tua mahasiswa.

\section{SIMPULAN}

Perceived Usefulness dari persepsi tersebut manfaat yang didapatkan informan ditunjukan perilaku dalam sikap yang santai dan tidak ribet harus bolak-balik kampus, perilaku sikap tanggap dan cepat mendapatkan informasi sehingga memberikan efisiensi dalam hal waktu. Melakukan sendiri tanpa diwakilkan ke orang lain menunjukkan bahwa nyaman dalam menggunakan. Dampak positif terlihat dari perilaku tetap bertahan menggunakan SIM UNIPMA untuk memprogram KRS merupakan kewajiban dari mahasiswa. Perceived ease to use dari persepsi tersebut menunjukan sikap percaya diri lebih santai dan meningkatkan keinginan untuk berusaha melakukan sendiri serta terlihat adanya sikap hatihati. KRS daring bisa dibuka dimana saja mempengaruhi perilaku mahasiswa merasa lebih santai walapun ada perilaku tidak tenang dan sedikit mengalah ketika tidak ada jaringan internet dan server penuh. Persepsi Kemudahan dan kebermanfaatan yang dirasakan bisa menjadi faktor yang mempengaruhi lancarnya pendapatan UNIPMA.

Keterbatasan penelitian tidak bisa secara langsung melihat informan ketika melakukan pemrograman KRS karena waktu pelaksanaan penelitian tidak bersamaan dengan jadwal pemrograman KRS. Saran peneliti untuk peneliti selanjutnya ketika melakukan penelitian sekalian membuka SIM UNIPMA agar bisa bertanya lebih detail dan mengungkap secara mendalam manfaat yang harusnya didapatkan oleh pengguna sistem tersebut. Adapula saran untuk perancang sistem bisa dipertimbangkan user interface yang masih belum sesuai jika ditampilkan di handphone agar lebih nyaman lagi, karena saat ini yang mudah dibawa kemana saja adalah handphone. Menjaga server tidak penuh serta mengkategorikan mata 
kuliah, kelas, dan semester untuk meminimalisir terjadinya kesalahan. Saran untuk pengambil keputusan mempertimbangkan kebutuhan waktu karena keberadaan dan kondisi mahasiswa berbeda mulai dari jangkauan jarak sampai jangkauan jaringan internet.

\section{REFERENCES}

Budiman. (2016). Pengaruh Pemanfaatan Sistem Akademik Online Terhadap Kepuasan Mahasiswa Menggunakan Technology Acceptance Model (TAM). Binis dan Iptek, 9(2), 110-128.

Davis, F. D. (1989). Perceived Usefulness , Perceived Ease of Use, and User Acceptance of Information Technology. MIS Quarterly, 13(3), 319-340.

Davis, F. D., Bagozzi, R. P., dan Warshaw, P. R. (1989). User Acceptance of Computer Technology: A Comparison of Two Theoretical Models. Management Science, 35(8), 982-1003.

Fatmasari, dan Ariandi, M. (2014). Penerapan Metode Technology Acceptance Model (TAM) Terhadap Penerimaan KRS Online. Jurnal Imiah MATRIK, 16(2), 135-144.

Fatmawati, E. (2015). Technology Acceptance Model (TAM) Untuk Menganalisis Penerimaan Terhadap Sistem Informasi Perpustakaan. Jurnal Iqra', 9(01), 1-13.

Firman, Rahmawati, R., dan Trijayanto, D. (2017). Penerimaan dalam E-Government (Studi Fenomenologi pada Pengguna Layanan Terpadu Satu Pintu di BPTSP DKI Jakarta). Promedia (Public Relation dan Media Komunikasi), 3(2), 274-302.

Handayani, T., dan Sudiana. (2015). Analisis Penerapan Model UTAUT Terhadap Perilaku Pengguna Sistem Informasi (Studi Kasus: Sistem Infomasi Akademik pada STTNAS Yogyakarta). Angkasa: Jurnal Ilmiah Bidang Teknologi, 7(2), 165-180.

Kamayanti, A. (2016). Metodologi Penelitian Kualitatif Akuntansi Pengantar Religiositas Keilmuan. Jakarta: Yayasan Rumah Peneleh.

Lenawati, M., dan Asnawi, N. (2018). Analisis Usability Sistem Informasi Akademik Mahasiwa Universitas PGRI Madiun Menggunakan Metode Heuristik. Prosiding. Seminar Nasional Teknologi Informasi dan Komunikasi Literasi Digital pada Era Revolusi Industri 4.0: Madiun.

Milad, M. K., Wibowo, A. T., dan Athoillah, Y. (2019). Penguatan Tata Kelola Transparansi
Informasi Publik, Akuntabilitas , dan Efisiensi Keuangan di Universitas Demi Mewujudkan Good University Government. Oeconomicus: Journal of Economics, 3(2), 91-104.

Nuryahya, E., Ichsana, Y., dan Andini, K. M. (2019). Perilaku Pengguna Sistem Informasi Akuntansi di E-Commerce. Jurnal Akuntansi Multiparadigma, 10(3), 502-515.

Putra, I. A. G. S. (2019). Penerapan Metode Technology Acceptance Model ( TAM) dalam Implementasi Resource Traffic Management System. Prosiding. Seminar Nasional Inovasi dan Aplikasi Teknologi di Industri: Malang.

Rakhmadian, M., Sefaverdiana, P. V., dan Rahman, N. (2019). Analisis Persepsi Kemanfaatan dan Persepsi Kemudahan Penggunaan Terhadap Penggunaan Sistem Informasi Akademik. Indonesian Journal on Computer and Information Technology, 4(2), 155-161.

Riyanto, T. P. S., Soedijono, B., dan Sunyoto, A. (2018). Analisis Kesuksesan Sistem Informasi KRS On-Line di Universitas AMIKOM Yogyakarta. Jurnal Teknologi Informasi, 13(1), 53-61.

Safitri, M. R., dan Indriani, M. (2017). Praktik Akuntansi Untuk Aset Bersejarah Studi Fenomenologi Pada Museum Aceh. Jurnal Ilmiah Mahasiswa Ekonomi Akuntansi, 2(2), 1-9.

Saputra, E., dan Misfariyan. (2013). Analisis Penerimaan Sistem Informasi Manajemen Rumah Sakit Umum Daerah Bangkinang Menggunakan Metode Technology Acceptance Model (TAM). Jurnal Sains, Teknologi \& Industri, 10(2), 1-7.

Saputra, H. S. (2019). Pengaruh Persepsi Kegunaan, Persepsi Kemudahan Penggunaan, dan Kepercayaan Terhadap Keputusan Penggunaan Jasa Layanan KAI Acces di Kota Malang. Jurnal Ilmiah Mahasiswa FEB, 7(2), 115.

Sutinah, A. dan Darmadji, S. H. (2013). Perancangan Sistem Akuntansi Siklus Pendapatan dalam Upaya Meningkatkan Pengendalian Internal pada Sekolah Tinggi Ilmu Kesehatan Katolik ST. Vincentius A Paulo Di Surabaya. Jurnal Ilmiah Mahasiswa Universitas Surabaya, 2(1), 215.

Thoyibatun, S. (2012). Faktor-Faktor yang Berpengaruh Terhadap Perilaku Tidak Etis dan Kecenderungan Kecurangaan Akuntansi Serta Akibatnya Terhadap Kinerja Organisasi. Jurnal Ekonomi Dan Keuangan, 16(2), 245-260.

Wiguna, S. M. (2015). Evaluasi Sistem Informasi Akuntansi Pada Siklus Pendapatan dan 
Penerimaan Kas Untuk Mengatasi Fraud Toko

SM di Jember. Jurnal Ilmiah Mahasiswa Universitas Surabaya, 4(2), 1-18.

Yusdita, E. E. (2017). Studi Interpretif Untuk Memahami Perilaku Keengganan Menggunakan E-Billing. Jurnal Akuntansi an Pendidikan, 6(1), 85-92. 